\section{Foundation for Stroke in Systemic Sclerosis: A Clarion Call for Proactive Assessment?}

\section{To the Editor:}

The study by Ying, et al ${ }^{1}$ of ischemic stroke risk in systemic sclerosis (SSc) reported increased prevalence (15.3 vs 12.2 per thousand in the control cohort) and delineated a series of likely predisposing comorbidities. There is an additional consideration, also amenable to risk adjustment: such events are also characteristic of the effect of antiphospholipid antibodies $(\mathrm{aPL})^{2}$. The reported prevalence of ischemic events in SSc is characteristic of that noted with aPL, a known association with connective tissue diseases, including $\mathrm{SSc}^{3,4,5,6}$. Prevalence of $14-18 \%$ has been observed in population studies of $\mathrm{SSc}^{6}$.

It may therefore appear surprising that the difference in stroke prevalence from that in controls was not greater than Ying, et al observed ${ }^{1}$. However, aPL have also been found in/responsible for a significant portion (17-22\%) of individuals under age 50 years (unaffected by SSc) with stroke ${ }^{7.8}$. Among healthy individuals, the aPL rate is $5 \%^{8}$; it is associated with a $5 \%$ annual risk increase of thrombosis ${ }^{9}$, increasing their risk 5 -fold ${ }^{8}$.

Varying prevalence of aPL has been reported in SSc, dependent on sample source and specific antibodies assessed. Sanna, et al ${ }^{5}$ noted IgG and IgM anticardiolipin antibodies in $24 \%$ and $16 \%$, respectively, compared with $5 \%$ and $3 \%$, respectively, in controls, and apolipoprotein $\mathrm{H}$ (anti- $\beta_{2}$-GPI) antibodies in a rheumatologic study, while Touré, et $a l^{4}$ reported 37 and $32 \%$ for the latter in a dermatology-derived sample.

It is apparent that aPL are not limited to SSc but are also present in otherwise apparently healthy individuals. However, they are especially common in those with SSc. Because there is effective intervention to prevent thromboembolic events in the presence of aPL and because such intervention requires a different approach (from thrombosis prevention in their absence $)^{10}$, would it not be reasonable to pursue routine screening for their presence? Recommended screening is for $\operatorname{IgG}$, $\operatorname{IgM}$, and $\operatorname{IgA}$ antibodies to anticardiolipin and to anti- $\beta_{2}$-GPI and perhaps antibodies to antiphosphatidylserine/prothrombin as well as for presence of the lupus anticoagulant ${ }^{2.5}$. It would be intriguing to prospectively identify the status of aPL (e.g., IgG, IgM, and IgA antibodies to anticardiolipin and anti- $\beta_{2}$-GPI and antibodies to antiphosphatidylserine/prothrombin) among individuals who are undergoing specific procedures (be they medical or aeronautic) and assess their post-procedure status.

BRUCE M. ROTHSCHILD (D), MD, Indiana University Health Ball Memorial Hospital, Muncie, Indiana, USA. Address correspondence to Dr. B.M. Rothschild, IU Health, 2401 W. University Ave., Muncie, Indiana 47303, USA. E-mail: spondylair@gmail.com

\section{REFERENCES}

1. Ying D, Gianfrencesco MA, Trupin L, Yazdany J, Greidninger EL, Schmajuk G. Increased risk of ischemic stroke in systemic sclerosis: a national cohort study of US veterans. J Rheumatol 2020;47:82-8.

2. Garcia D, Erkan D. Diagnosis and management of the antiphospholipid syndrome. N Engl J Med 2018;378:2010-21.

3. Cohen D, Berger SP, Steup-Beekman GM, Bloemenkamp KW, Bajema IM. Diagnosis and management of the antiphospholipid syndrome. BMJ 2010;340:2541.

4. Touré AO, Ly F, Sall A, Diatta A, Gadji M, Seck M, et al. Antiphospholipid antibodies and systemic scleroderma. Turk J Haematol 2013;30:32-6.

5. Sanna G, Bertolaccini ML, Mameli A, Hughes GR, Khamashta MA, Mathieu A. Antiphospholipid antibodies in patients with scleroderma: Prevalence and clinical significance. Ann Rheum Dis 2005;64:1795-6.

6. Martin M, Martinez C, Arnaud L, Weber JC, Poindron V, Blaison G. Association of antiphospholipid antibodies with active digital ulceration in systemic sclerosis. RMD Open 2019;5:e01012.

7. Andreoli L, Chighizola CB, Banzato A, Pons-Estel GJ, Ramire de Jesus G, Erkan D, on behalf of APS Action. Estimated frequency of antiphospholipid antibodies in patients with pregnancy morbidity, stroke, myocardial infarction, and deep vein thrombosis: a critical review of the literature. Arthritis Care Res 2013;65:1869-73.

8. Sciascia S, Sanna G, Khamashta MA, Cuadrado MJ, Erkan D, Andreoli L, et al. The estimated frequency of antiphospholipid antibodies in young adults with cerebrovascular events: a systematic review. Ann Rheum Dis 2015;74:2028-33.

9. Pengo V, Ruffatti A, Legnani C, Testa S, Fierro T, Marongiu F, et al. Incidence of a first thromboembolic event in asymptomatic carriers of high-risk antiphospholipid profile: a multicenter prospective study. Blood 2011;118:4714-18.

10. Collision J. End of the road for direct oral anticoagulants in thrombotic APS? Nature Rev Rheumatol 2019;12:697.

First Release April 1 2020; J Rheumatol 2020;47:6; doi:10.3899/jrheum.200070 